\title{
The uncovered volumes of bushmeat commercialized in the Amazonian trifrontier between Colombia, Peru \& Brazil
}

\author{
Nathalie van Vliet*, Maria Paula Quiceno-Mesa², Daniel Cruz-Antia², Lindon Jonhson Neves de Aquino , Jessica Moreno² \\ and Robert Nasi'
}

\begin{abstract}
The Importance of bushmeat trade in Amazonian towns has been very little studied, either because it is thought to be insignificant or due to the context of illegality. Based on preliminary field work to identify the main stakeholders involved and the existing trade routes, our study aimed at describing the invisible bushmeat trade using a participatory monitoring protocol in Leticia and Puerto Nariño in Colombia, Tabatinga, Benjamin Constant and Atalaia do Norte in Brazil, and Santa Rosa and Caballococha in Peru. The monitoring system included two key levels of the market chain: hunters and market traders. With the support of our research team, the hunters and traders self monitored their activities during 60 days and 20 days respectively during two hydro-climatic periods. Our study shows that the most hunted species are paca, tericaya turtle and currassows while the most commercialized species are paca, tapir, collared peccary and the red brocket deer. We registered a total of 13 tons of bushmeat captured by hunters (from 29 species) and 6.7 tons of bushmeat sold by market sellers (from 19 species). We extrapolated this data to a year and to the total numbers of stakeholders involved in the trade and found that 473 tons of bushmeat are traded per year in market places from the main Tri frontier towns, which taken to the total urban population size of the area, equals to 3.2 $\mathrm{kg} / \mathrm{hab} / \mathrm{year}$, a number that is comparable to those found in Central African urban settings.
\end{abstract}

Keywords: Bushmeat trade, Amazon, Colombia, Brazil, Peru

\section{INTRODUCTION}

Wildlife used for human consumption, frequently called "bushmeat" is often still fundamental for the subsistence of rural communities in the Amazon (Bodmer and Lozano 2001; Bodmer et al. 2004; Ojasti 2000), despite the rapid social and economic transformations that push rural livelihoods away from the dependency on forest products (Sills et al. 2011). The numerous studies available on bushmeat in the Amazon have focused on understanding hunting practices and offtakes, most often in indigenous and rural contexts (Maldonado 2010; Payan 2009; Ayres and Ayres 1979; Bodmer et al. 1997; Emídio-Silva 1998; Lopes and Ferrari 2000; Peres 2001; Zapata-Ríos 2001; Bodmer et al. 2004; Bonaudo et al. 2005; Hurtado-Gonzalez and Bodmer 2004; Zapata-Rios et al. 2009; Shepard et al. 2012; Iwamura et al. 2014). Rural consumption of bushmeat is believed to equal to about 150000 tons/year in the Amazon, which is equivalent to a consumption of about $63 \pm$ $25 \mathrm{~kg} / \mathrm{capita} /$ year (Nasi et al. 2011).

1 Center for International Forestry Research, alan CIFOR Situ Gede, Sindang Barang Bogor (Barat) 16115. Indonesia. Corresponding author. E-mail adresses: NVV (vanvlietnathalie@yahoo.com), MPQ (dhuryi@gmail.com), DC (danielcruz@fundsi.org), LJN (lj. aquino@ bol.com.br), JM (jessical.morenoc@gmail.com),RN (r.nasi@cgiar.org)

2 Fundación SI-Science International Calle 28 № 13 A -24 oficina 308. Bogotá-Colombia

3 Universidade Federal do Amazonas, Instituto Natureza e Cultura - campus Alto Solimões- Rua 1 de Maio Colônia Benjamin Constant-Brazil 
While hunting patterns in rural indigenous areas in the Amazon are relatively well known, there is almost no published information about the bushmeat trade in urban areas. Rushton et al. (2005) consider urban bushmeat trade in the Amazon as negligible because of the availability and prices of domestic sources of protein. Nevertheless, the assumption is not yet tested given the almost un-existent information on bushmeat trade in open-air markets in urban centers throughout the Amazon region (Sampaio 2003; Bodmer et al. 2004). Commercialization occurs in largely hidden markets and information on bushmeat trade is difficult to obtain, mainly because buying and selling wildlife is an illegal activity in all Amazonian countries. Most of the data available to managers is derived from confiscations of bushmeat by environmental agencies during inspection activities, but the quality of this datasets are questionable in terms of their representativeness of the overall trade. The best known and largest wild game market in the Amazon is in Iquitos Peru where for instance in the 1990s bushmeat prices could reach US $\$ 4$ per kg (e.g., for meat from the highly prized paca Cuniculus paca) and the meat from an individual large peccary could be worth as much as US\$60 with the hide bringing in an additional US $\$ 10$ to the hunter (Bodmer and Lozano 2001; Claggett 1998). This market arose due to the lack of cattle ranching in this part of the lowland Amazon. A study conducted in Pompeya, Ecuador (WCS, 2007) reported 13 tons of bushmeat (corresponding to 56 especies) sold per year in the local market. Another recently studied market in the Amazon is that of Abaetetuba (Pará-Brazil), conducted by Baía et al. (2010). The authors showed that the biomass of bushmeat traded during the study period was equivalent to about 6 tons of bushmeat (in 17 days monitored throught the year), most of which was of capybara (Hydrochoerus hydrochaeris) and caiman meat (Melanosuchus niger and Caiman crocodilus crocodilus).

Understanding the structure of the market chain and estimating the contribution of urban areas to the overall use of bushmeat, is crucial to formulating recommendations for the sustainable use of wildlife. For example, in Central Africa, given the important contribution of urban consumption in the bushmeat trade, urban markets have been widely used to estimate the state of hunted faunal assemblages and infer the sustainability of hunting (Juste et al. 1995; Brashares et al. 2004; Albrechtsen et al. 2005; Cowlishaw et al. 2005; Crookes et al. 2005; Wilkie et al. 2005; de Merode and Cowlishaw 2006; Fa et al. 2006; Brugiere and Magassouba 2009). Bushmeat markets are found in almost every town and village in Central Africa and are important concentration points of wildlife harvests from surrounding hunting catchments (Juste et al. 1995; Fa et al. 2000; Fa and Yuste 2001). Where bushmeat trade exists, managers should have a better knowledge of the structure of the bushmeat trade, the extend of the catchment areas, the actors involved and the quantities and quality of bushmeat sold, to formulate realistic management recommendations. As suggested by van Vliet et al. (2012), market data can provide valuable information to policy makers and managers by raising the alarm when rapid changes are observed, indicating the capacity of particular sources of protein to become substitutes for bushmeat, describing the role of prices in consumer choices and analyzing the effects of policy and management decisions on food security and conservation.

Given the importance of bushmeat trade data, our motivation for this study was to answer the following questions: Is bushmeat trade so insignificant as suggested by Rushton et al. (2005) that it is not worth the affort? Is it because it is invisible, occurs in hidden markets and is difficult to assess due to illegality? Or is it because public institutions and research have provided little efforts and interest in quantifying its importance? The main motivation of this study is to quantify and describe the volumes and quality of bushmeat sold in the main towns of the Tri-frontier towns, using a participatory monitoring protocol with the active participation of stakeholders of the bushmeat trade chain. 


\section{MATERIAL AND METHODS}

\section{Study Site}

\section{Human population}

The study was carried out during 2013 in the tri-national frontier region between Colombia, Peru and Brazil (Figure 1). We sampled eight localities, two in Colombia [Leticia (37,832 inhab.), Puerto Nariño (6,983 inhab., including Loretoyacu River communities and peri-urban communities near Leticia)], three in Peru [Caballococha (7,885 inhab.), Santa Rosa and Atacuari River communities] and another three in Brazil [Tabatinga (52,272 inhab.), Benjamin Constant $(33,411$ inhab.) and Atalaia do Norte (15,153 inhab.)] (DANE 2007; IBGE 2010; INEI 2008; INEI 2011). These human populations have resulted from different waves of migrants of indigenous (mostly Ticuna \& Yagua in Peru, Ticuna, Cocama, Yagua \& Uitoto in Colombia and Ticuna in Brazil), colonos and mestizo origins from different countries (INEI 2010; Suárez-Mutis et al. 2010).

The local economy is mainly based on small slash-and-burn cultivation (chagras) and some trade. The agricultural food production, which is poor in protein, is complemented by hunting and fishing (Eden 1990). Tourism also provides alternative income, and the illicit trade (drug trafficking and illegal extraction of cedar (Cedrela spp.) continues to contribute to the dynamic economy of the region (Riaño 2003; Zarate 2008). In the urban towns of the tri-frontier, the local economy relies on drug traffic (particularly on the Peruvian border), wood extraction (in Brazil and Peru), and governmental subsidies, small businesses, fishing and tourism.
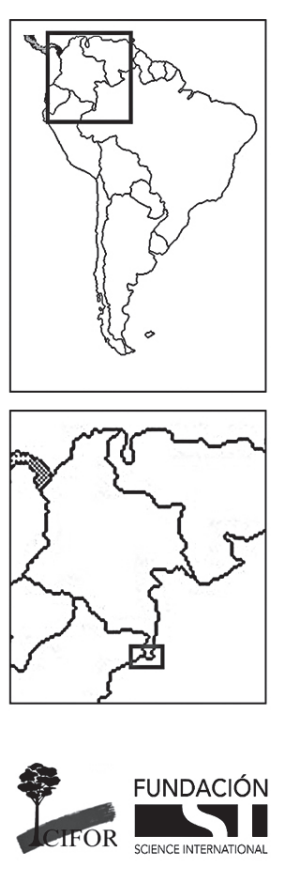

Figure 1. Study area, the Amazonian triborder frontier.

\section{Environmental conditions}

The study area has a unimodal-biseasonal rainfall distribution type, with an average precipitation of $3,270 \mathrm{~mm}$ and a monthly average of $266 \mathrm{~mm}$ (Domínguez 1985); lowest rainfall is typical in August. Rain increases in September with a sharper increase between January and
April, the wettest month of the year (Rudas and Prieto 2005). Dry conditions at the site and the low rainfall upriver along the Eastern slopes of the Andes, results in a substantial drop in the water level during the July-September interlude. The maximum water level occurs in May $(1,686 \mathrm{~cm})$, dropping to its lowest mark in September $(445 \mathrm{~cm})$ 
(Domínguez 1985). Average temperature is $26.2 \mathrm{C}$ with an mean relative humidity of over $86 \%$.

The region is still largely forested, divisible into eight main habitat types, though largely composed of terra firme forest (dry unflooded areas), varzea forest (regularly flooded by white waters) and marshy forests (flooded by black waters in certain seasons) (Prance 1979). The Colombian side is characterized by terra firme forests up to Puerto Nariño, whereas the Brazilian and Peruvian sides are covered by marshy and varzea forests. Natural habitats are increasingly transformed by human economic activities: mainly through the urbanization around towns, shifting cultivation and ranching on the Colombian border, coca fields and cash crops in Peru and logging and oil palm plantations on the Brazilian side.

\section{Methods}

We conducted a preliminary study to describe the bushmeat market chain using participatory observations, interviews and participatory mapping (van Vliet et al. 2014). Eight main actors were involved: hunters, intermediaries, wholesalers, retailers, market sellers, formal restaurants and street food stalls. This accounted for 195 active stakeholders that participate in the trade chain. Because the wild meat trade is illegal, 3-4 months were spent penetrating the situation through discussions with consumers, identifying and approaching traders and engaging in informal dialogue, sharing meals, and traveling with them to potential source areas. This investment of time was crucial to gain the confidence of the different stakeholders. Also, as a follow up to the preliminary study, and in order to estimate the amount of total bushmeat being commercialized in the Tri frontier, we developed a participatory monitoring tool which we applied at two key levels of the trade chain: hunters and market sellers.

We gathered data by utilizing local hunters and market sellers (see Table 1 for sampling effort based on information generated by van Vliet et al. (2014). Monitors were chosen according to two main criteria: 1) good geographical representation of the sample; and 2) a willingness and trust to participate in the project. In addition, for the hunters, we attempted to have the two main hunter types described in van Vliet et al. (2014) represented: 4 specialized hunters (for whom hunting is the main economic activity) and 4 diversified hunters (for whom hunting is part of a diversified livelihood strategy). Our sampling for hunters did not include anyone from Peru because hunters in Peru usually come from very remote indigenous communities along the Atacuari river ( 8 to 12 hours by boat from Caballococha) and it would have been logistically impossible to follow up.

A monitoring notebook, to record all quantities, species and state (fresh, salted, smoked) of the bushmeat harvested or sold were designed and distributed among the recorders. For hunters, we also obtained information on hunting areas, main prey hunted, and whether the bushmeat was sold or for family consumption. The monitoring period covered two hydro-climatic phases: one in May and another one in September 2013 (high and low level waters respectively).

Because market sellers practiced their activity on a daily basis whereas hunters only hunt one out of 3-5 days, market sellers were asked to record data for 10 consecutive days, whereas hunters monitored their activities during a 30-day period. This meant that over a month we gathered data for about 10 hunting days for each actor during each period. To ensure the quality of self-reported data was adequate, we chose to limit the monitoring period to a short representative period, rather than having a long term and non-terminal monitoring system which would have probably create biases due to research fatigue. In addition, to ensure greater accuracy, the researchers visited market sellers on a daily basis and the hunters every five days during the monitoring period. A participant observation monitoring was also developed during the whole duration of the study (from August 2012 to September 2013) in order to triangulate the data recorded. Frequent informal visits to the main market places were undertaken in the selected settlements (5 - 8 am each day) during the setting up of meat stalls and just before closing time (11am to $12 \mathrm{pm})$. Species commercialized, as well as prices and quantities were also recorded. Informal conversations with market sellers and restaurant owners allowed us to gain further qualitative information about their activities. 
Table 1. Sampling of actors participating in the bushmeat monitoring protocol.

\begin{tabular}{|c|c|c|c|c|}
\hline & ion & Users & $\begin{array}{c}\text { Number of } \\
\text { monitors } \\
\text { participating }\end{array}$ & $\begin{array}{c}\text { Number of } \\
\text { stakeholders } \\
\text { identified }\end{array}$ \\
\hline \multirow[t]{4}{*}{ Colombia } & Puerto Nariño & Hunters & 2 & 40 \\
\hline & & Hunters & 2 & 8 \\
\hline & Leticia & & & \\
\hline & & Market sellers & 2 & 6 \\
\hline Peru & Caballococha & Market sellers & 2 & 9 \\
\hline \multirow[t]{6}{*}{ Brazil } & Tabatinga & Market sellers & 2 & 6 \\
\hline & & Hunters & 2 & 31 \\
\hline & Benjamin Constant & & & \\
\hline & & Market sellers & 2 & 5 \\
\hline & Atalaia do Norte & Hunters & 2 & 12 \\
\hline & Total & & $16(14 \%)$ & 117 \\
\hline
\end{tabular}

Biomass caught by hunters was estimated by multiplying the number of animals reported for each species by the average weight per specimen in Kg (based on Emmons and Feer (1997)), taking into account that we used $75 \%$ of the average adult weight to diminish the weight of bones and head for the biggest species. The proportion of sold meat was estimated in kilogrames by each hunter when a trading event was registered. Quantities of bushmeat reported by market sellers were weighted by themselves using their own weighing tools and checked by the researchers during the monitoring periods.

\section{RESULTS}

\section{Species composition and bushmeat harvested and sold by hunters}

The most commonly hunted taxonomic group were mammals $(60 \%)$, birds $(26 \%)$ and reptiles (14\%). In total, 485 individuals were hunted in 60 days, equivalent to 13 tons of meat. A total of 27 species were traded and hunted in Colombia and
17 in Brazil. During the first period (high water level), hunters extracted a total of 5.24 tons of bushmeat, of which $79 \%$ came from hunters from Benjamin Constant and Atalaia do Norte. During the second period (low water level), we estimated a total of 7.75 tons harvested, of which $95 \%$ was from hunters from Brazil. We found that Colombian hunters mostly used bushmeat for their own consumption (74\% of the biomass was consumed by them), whereas Brazilian hunters sold most of the meat extracted ( $96 \%$ of the biomass was sold). Dasyprocta fuliginosa, C. paca, P. unifilis, Crax sp, T. terrestris, Lagothrix lagotricha, and Crypturellus sp. contributed $61 \%$ of the total catch during the two periods (Figure 2). For the colombian hunters Dasyprocta fuliginosa and C. paca contributed to $42 \%$ of the biomass harvested (from a total of 107 individuals), whereas Brazilian hunters captured $C$. paca, $P$. unifilis, Crax sp and T. terrestris equivalent to $50 \%$ of the total biomass harvested from a total of 379 individuals. 


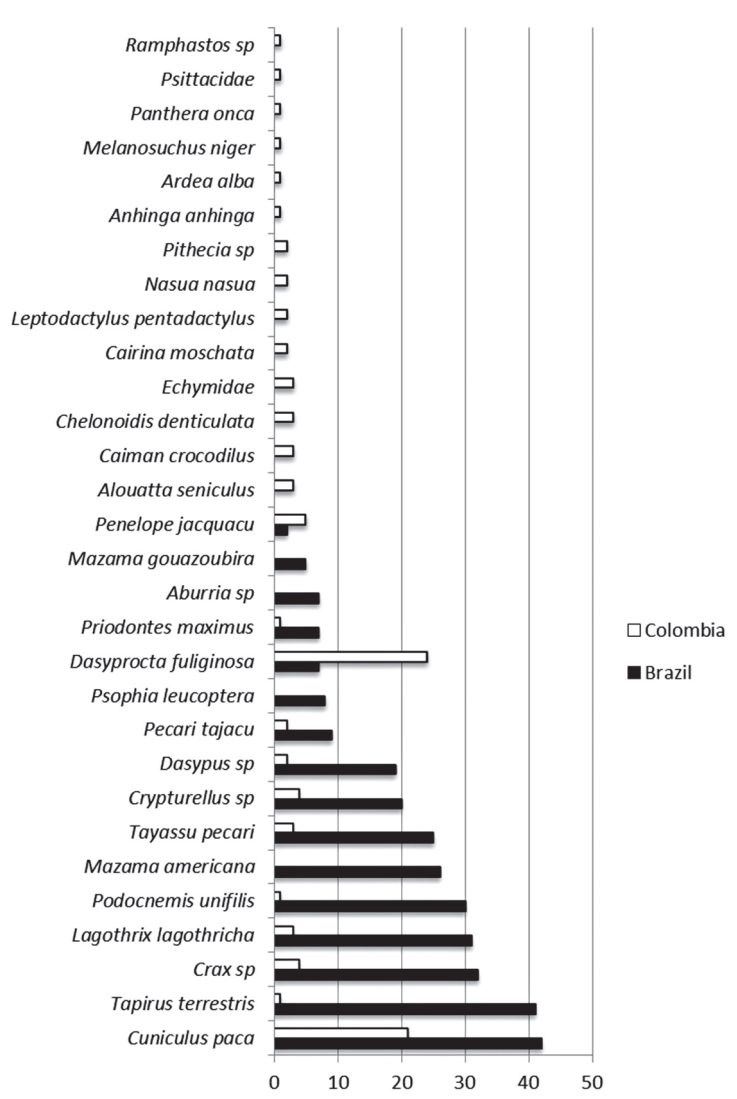

Figure 2. Species and number of individuals hunted by Colombian and Brazilian hunters

Most prey was hunted in primary forests $(62 \%$ of catch). Brazilian hunters caught most of their catch in primary forests $(74 \%)$, while Colombian hunters diversified hunted animals in primary forests $(33 \%$ of the catch), secondary forests $(31 \%)$ and riparian forests (23\%). During low water level, most of the game was from primary forests $(71 \%)$ and streams $(19 \%)$, while during high water level the catch originated from secondary forests $(22 \%)$, flooded areas $(21 \%)$, riparian forests $(16 \%)$ and primary forests $(38 \%)$. We also found that out of 100 hunting trips registered in the two periods by colombian hunters, $72 \%$ lasted between 0 and 5.9 hours of effort, $13 \%$ took from 6 hours to 2 days and $2 \%$ were hunting trips of more than two days. On the opposite, from 53 hunting trips registered in the two periods by Brazilian hunters, $64 \%$ took from 6 hours to 2 days and $36 \%$ were hunting trips of more than two days.

\section{Bushmeat commercialized in market places}

Nineteen bushmeat species were sold by market traders during the two sampled periods. Mammals contributed $74 \%$ of the total catch, whereas birds and reptiles accounted for $16 \%$ and $10 \%$ respectively (Figure 3 ). The most commercialized species in Brazilian markets were paca, tapir and the collared peccari, representing $47 \%$ of their total biomass traded. In Peruvian markets paca and the yellow footed tortoise (Chelonoidis denticulata) represented $50 \%$ of biomass. As in the case of Colombian traders, paca represented $48 \%$ of the total biomass.

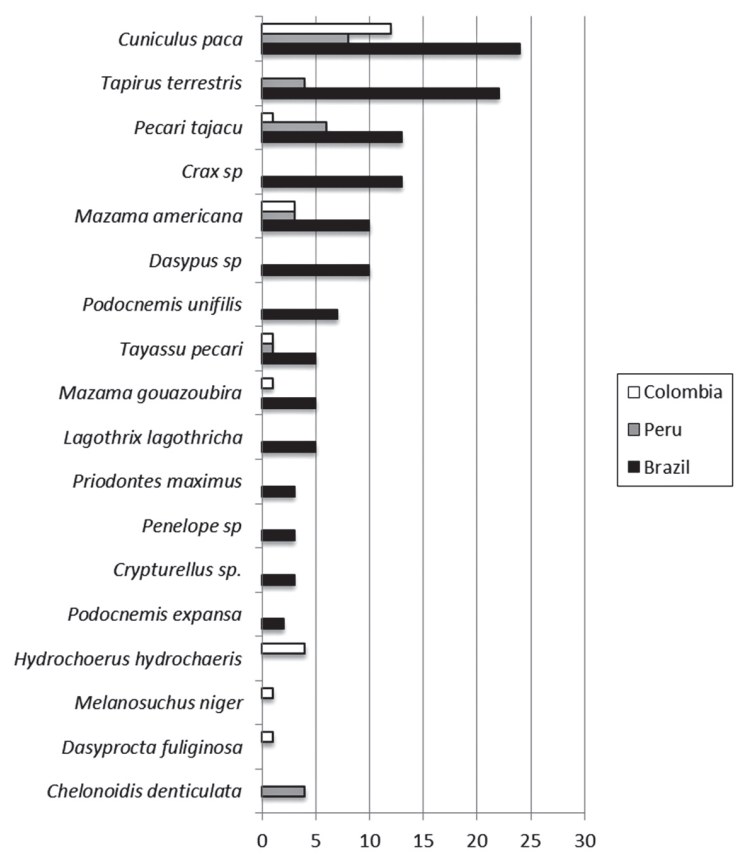

Figure 3. Number of reports of species traded during high and low-level Waters in market places.

A total of 3.7 tons of bushmeat were sold during the high water level period and 3 tons during the low water level period by the 8 traders during the 10 monitoring days in each season. During the two periods, traders in the Brazilian section contributed $80 \%$ of all biomass sold in the first period (equivalent to 2.960 tons) and $75 \%$ in the second (equivalent to 2.27 tons). In total, 6.7 tons of bushmeat were traded during the two periods monitored ( 20 days) in the four selected localities. 
Bushmeat was mostly sold fresh in Leticia $(81 \%)$, whereas bushmeat was mostly found smoked in Caballococha (56\%) and salted (38\%) and iced $(32 \%)$ for the case of Tabatinga and Benjamin. The main clients of bushmeat traders in markets were colono or mestizo families, restaurant owners and public authorities. Coca workers were the main clients of market sellers in Caballococha. During the two monitored periods, fresh bushmeat was purchased at a price of USD $\$ 3.81 / \mathrm{kg}$ by market traders to the hunter or intermediar (Table 2). The average price for customers in the market place was USD $\$ 5.32 / \mathrm{kg}$. Prices remained relatively stable all along the year and bushmeat was about four times cheaper than chicken and at comparable prices with beef. Given enforcement, market sellers are unable to increase prices when bushmeat becomes scarcer (dry season). Smoked or salted bushmeat was about $20 \%$ cheaper than fresh bushmeat.

Table 2. Commercialization form, average buying price, average sale prices per kilogram (USD\$/kg) of most traded animal proteins

\begin{tabular}{|c|c|c|c|c|c|c|c|c|c|}
\hline \multirow[t]{2}{*}{$\begin{array}{l}\text { Type of } \\
\text { protein }\end{array}$} & \multirow[t]{2}{*}{$\begin{array}{c}\text { Commercialization } \\
\text { form }\end{array}$} & \multicolumn{3}{|c|}{$\begin{array}{c}\text { Average buying price } \\
\text { (USD) }\end{array}$} & \multirow{2}{*}{\begin{tabular}{|c|} 
Average \\
buying price \\
consolidated \\
(USD) \\
\end{tabular}} & \multicolumn{3}{|c|}{$\begin{array}{c}\text { Average selling price } \\
\text { (USD) }\end{array}$} & \multirow[t]{2}{*}{$\begin{array}{c}\text { Average } \\
\text { buying price } \\
\text { consolidated } \\
\text { (USD) }\end{array}$} \\
\hline & & Colombia & Peru & Brazil & & Colombia & Peru & Brazil & \\
\hline \multirow[t]{5}{*}{ Bushmeat } & Smoked & -- & 2.79 & -- & 2.79 & -- & 3.94 & -- & 3.94 \\
\hline & Salted & -- & 2.06 & 3.46 & 2.76 & -- & 3.43 & 5.2 & 4.31 \\
\hline & Fresh & 4.23 & 3.83 & 3.38 & 3.81 & 6.81 & 4.44 & 4.72 & 5.32 \\
\hline & Iced/frozen & 4.65 & -- & 3.42 & 4.03 & 5.99 & -- & 5.13 & 5.56 \\
\hline & Live animal & -- & 27.78 & 20.35 & 24.06 & -- & 36.5 & 34.93 & 35.7 \\
\hline Beef & Fresh & ND & ND & ND & ND & 7.23 & 5.17 & 7.58 & 6.2 \\
\hline Chicken & Frozen & ND & ND & ND & ND & 0.98 & 0.98 & 1.75 & 1.24 \\
\hline
\end{tabular}

$N D=$ No Data.

\section{DISCUSSION}

In methodological terms, our approach shows that participatory approaches are a valuable tool to involve stakeholders in local monitoring mechanisms. As a result of the difficulties in assessing sustainability with oneoff indicators, the monitoring of harvested and traded populations through time is one of the gold standards in sustainability monitoring (Weinbaum et al. 2013). Ideally, bushmeat monitoring is an on-going process and is accompanied by information about the political, social, economic and ecological context to inform adaptive management strategies (Johnson et al. 2002). As pointed out by van Vliet et al. (2012) bushmeat monitoring data when combined with longitudinal information from along the supply chain (wildlife populations, hunters, traders and consumers) can provide valuable information to policy makers and managers by raising the alarm when rapid changes in the characteristics of the harvest and trade are observed.

Our study shows that a larger proportion of the harvest is sold on the Brazilian side, as compared to the Colombian side. Colombian hunters harvest mainly pacas and black agouties, which are species associated to secondary and transformed habitats and practice garden hunting in combination to other subsistence activities. On the other hand, Brazilian hunters target tapirs and the terecaya turtles which involve a higher investment in time, organization and economic efforts. In Peruvian markets the yellow footed tortoise is also frequently captured and traded due consumption preferences among clients. Bushmeat is mostly sold fresh in Colombia, smoked in Peru and salted or iced in Brazil. 
Differences in law enforcement, distance to hunting grounds, vegetation cover in hunting grounds, local governance and ethnic origin across the borders, probably explain the prey and state differences observed. Hunters in Brazil are specialised caboclo hunters, either hunting in secondary forests in peri-urban areas, or traveling to remote hunting grounds in terra firme forest along the Javari river (spending about 4 days in their remote hunting camps). Hunters in Peru are indigenous men who live and hunt along the Atacuari river in terra firme and varzea forests (8-12 hours boat from Caballococha). The main clients in Caballococha are coca field workers who purchase smoked busmeat as their preferred food as it is light enough and can be easily transported and preserved in remote forest camps. Hunters from Colombia are mainly indigenous men from legally recognized indigenous territories, who hunt in the secondary forests from peri-urban areas of Leticia, in fallow land when hunting is combined with farming or along streams running towards the Amazon river.

Overall, the most hunted species are paca, tericaya turtle and currassows (Crax sp.) while the most commercialized species are paca, tapir, collared peccary and the red brocket deer (Mazama americana). This finding shows that some species are filtered along the market chain, to the advantage of medium to larger sized mammals at the bottom end of the trade chain. The reasons behind this are not yet completely understood. Some species may disappear or remain along the market chain because of their commercial value, their taste (e.g. paca is largely preferred for its taste in our study site), their cultural importance (e.g. the turtle for birthdays in the Brazilian Amazon), or associated taboos (e.g. giant armadillo (Priodontes maximus) and pink river dolphins (Inia geoffrensis, Sotalia fluviatilis) among indigenous communities).

Among the most traded species, peccary and paca are listed as "Least Concerned", red brocket deer is listed as "Data Deficient" and tapir is listed as "Vulnerable" by the IUCN red list (IUCN 2013). The paca is widely distributed throughout the Neotropics and its delicious and tender meat is greatly enjoyed throughout its range (Pérez 1992). Given it's biological parameters, this species has been identified as an excellent candidate for domestication (Smythe 1987). The species is classified as least concerned by the IUCN RED list in view of its wide distribution, presumed large population, occurrence in a number of protected areas, and because it is unlikely to be declining at nearly the rate required to qualify for listing in a threatened category. However, local extinctions have occurred in the southeast of its range due to habitat destruction. Pecari tajacu is widely distributed and occurs in a variety of habitats, including woodlands, tropical dry and rainforests, savannas, Gran Chaco, and deserts, from the southern USA through to northern Argentina. However, given the continuing rates of habitat destruction and potential for over-hunting of this species, the status of all populations requires monitoring. Mazama americana is considered to be "data deficient" in light of continued taxonomic uncertainty. Until the systematics of this taxa are better understood it is impossible to evaluate it against the categories and criteria of the IUCN Red List. Hunting of red brocket deer was evaluated to be sustainable in the Peruvian Amazon (HurtadoGonzales and Bodmer 2004). Tapirus terrestris is considered to be Vulnerable due to an ongoing populations reduction estimated to be slightly greater than a $30 \%$ in the past 3 generations ( 33 years) due to habitat loss, illegal hunting and competition with livestock. Tapir hunting was found to be unsustainable in French Guyana (Tobler et al. 2013). Yet, the study was based on the use of the over simplified Robinson and Redford (1992) model, which does not take spatial factors in to account. Shape of the hunted area and the size of the surrounding population are key factors that influence the sustainability of tapir hunting (Salas and Kim 2002; Novaro et al. 2000).

The limited number of market sellers identified in the tri-frontier catchment area and the fact that the trade occurs in clandestine networks, can provide the erroneous idea that the volumes traded are insignificant. However, our study shows that a total of 6.7 tons were traded by 8 market sellers in 20 days. If we extrapolate our data for the whole year (taking into account the mean volume sold in each of the seasons) and assuming that all the 29 active market sellers in the Tri Frontier towns (Leticia, 
Tabatinga, Caballococha, Benjamin Constant, Atailaia do norte) trade a volume equal to the mean of sales per trader, the total volume of bushmeat traded is equal to 473 tons per year for a total urban population of 146555 habitants $(3.4 \mathrm{~kg} / \mathrm{hab} /$ year). These results are 3 times higher than those found by Baia et al. (2010) in Abaetetuba $(130000$ habitants): 6 tons in 17 days, equivalent to about 128 tons per year $(0.98 \mathrm{~kg} / \mathrm{hab} /$ year). In the Congo Basin, Chardonnet et al. (1995) report that urban populations in Gabon, DRC and CAR consumed on average $4.7 \mathrm{~kg} /$ person/year; consumption in Libreville (Gabon) is estimated at $7.2 \mathrm{~kg} /$ person/ year (Wilkie et al. 2005), in Bangui (CAR) at $14.6 \mathrm{~kg} /$ person/year (Fargeot and Dieval 2000), in Mbanjock (Cameroon) at $2 \mathrm{~kg} /$ person/year.

\section{CONCLUSIONS}

Our results show that bushmeat trade in Amazonian towns is not negligeable as compared to what is observed in Central African contexts, and that bushmeat trade in the Amazon is instead alarmingly uncovered by scientific research. The existing but clandestine market observed calls for exploring the conditions in which it would be possible to legalize a local scale trade for resilient species so as to maintain the cultural, economic and social services provided by wildlife, while enforcing the trade of more vulnerable and protected ones.

\section{ACKNOWLEDGEMENTS}

We acknowledge the active contribution of all stakeholders in the trade chain that actively participated in this work, always maintaining a great spirit of collaboration and rigorous research principles. This work would not have been possible without the support from the University of Sao Paolo, UFAM and UEA in Brazil and the National University and Fundación Omacha in Colombia. This work was supported by funding from USAID and UKAID through the CGIAR research program on Forests, Trees and Agroforestry and CIFOR bushmeat research initiave.

\section{REFERENCES}

1. Albrechtsen L, Fa JE, Barry B, Macdonald DW (2005) Contrasts in availability and consumption of animal protein in Bioko Island, West Africa: the role of bushmeat. Environmental Conservation 32(4):340-348.

2. Ayres JM, Ayres C (1979) Aspectos da caça no alto rio Aripuaña. Acta Amazonica 9(2):287- 298.

3. Baía JrPC, Guimarães DA, Le Pendu Y (2010) Non-legalized commerce in game meat in the Brazilian Amazon: a case study. Revista de biología tropical 58(3):1079-1088.

4. Bodmer RE, Lozano EP (2001) Rural development and sustainable wildlife use in Peru. Conservation Biology 15(4):1163-1170.

5. Bodmer RE, Lozano EP, Fang TG (2004) Economic analysis of wildlife use in the Peruvian Amazon. In: Silvins KM, Bodmer R, Fragoso JMV (eds) People and nature: wildlife conservation in South and Central America. Columbia University, New York, pp. 191-207

6. Bodmer RE, Eisenberg JF, Redford KH (1997) Hunting and the likelihood of extinction of Amazonian mammals. Conservation Biology 11:460-466.

7. Bonaudo T, Le Pendu Y, Faure JF, Quanz D (2005) The effects of deforestation on wildlife along the transamazon highway. European Journal of Wildlife Research 51(3):199-206.

8. Brashares JS, Arcese P, Sam MK, Coppolillo PB, Sinclair ARE, Balmford A (2004) Bushmeat hunting, wildlife declines and fish supply in West Africa. Science 306(5699):1180-1183.

9. Brugiere D, Magassouba B (2009) Pattern and sustainability of the bushmeat trade in the Haut Niger National Park, Republic of Guinea. African Journal of Ecology 47(4):630-639.

10. Chardonnet $P(1995)$ Faune sauvage Africaine: la ressource oubliée. International Game Foundation, CIRAD-EMVT, Luxembourg.

11. Claggett PR (1998) The spatial extent and composition of wildlife harvests among three villages in the Peruvian Amazon. 1998 meeting of the Latin American Studies Association. The Palmer House Hilton Hotel, Chicago, Illinois.

12. Cowlishaw G, Mendelson S, Rowcliffe JM (2005) Evidence of post-depletion sustainability in a mature bushmeat market. Journal of Applied Ecology 42(3):460-468.

13. Crookes DJ, Ankudey N, Milner-Gulland EJ (2005) The value of a longterm bushmeat market dataset as an indicator of system dynamics. Environmental Conservation 32(4):333-339.

14. DANE. 2007. Censo general 2005. [http://www.dane.gov.co/index. php?option=com_content\&view=article\&id=307\& Itemid=124] Accessed 23 January 2014

15. De Merode E, Cowlishaw G (2006) Species protection, the changing informal economy, and the politics of access to the bushmeat trade in the Democratic Republic of Congo. Conservation Biology 20(4):1262-1271.

16. Domínguez C (1985) Amazonia Colombiana: Visión General. Biblioteca Banco Popular. Bogotá, Colombia

17. Eden MJ (1990) Ecology and land management in Amazonia. Belhaven Press, London, U.K.

18. Emídio-Silva C (1998) A caça de subsistência praticada pelos índios parakanã (Sudeste do Pará): características e sustentabilidade. MSc. Dissertation, Universidade Federal do Pará, Pará, Brazil 
19. Emmons L, Feer F (1997) Neotropical rainforest mammals: a field guide. 2 ed. University of Chicago Press, Chicago, USA

20. Fa JE, García Yuste JE, Castelo R (2000) Bushmeat markets on Bioko Island as a measure of hunting pressure. Conservation Biology 14(6):1602-1613.

21. Fa JE, Seymour S, Dupain J, Amin R, Albrechtsen L, Macdonald D (2006) Getting to grips with the magnitude of exploitation: bushmeat in the Cross-Sanaga rivers region, Nigeria and Cameroon. Biological Conservation 129(4):497-510.

22. Fa J, García Yuste JE (2001) Commercial bushmeat hunting in the Monte Mitra forests, Equatorial Guinea: extent and impact. Animal Biodiversity and Conservation 24(1):31-52.

23. Fargeot $C$, Dieval $S(2000)$ La consommation de gibier à Bangui, quelques données économiques et biologiques. Canopée 18:5-7.

24. Hurtado-Gonzales JL, Bodmer RE (2004) Assessing the sustainability of brocket deer hunting in the TamshiyacuTahuayo Communal Reserve, northeastern Peru. Biological Conservation 116(1):1-7.

25. INEI -Instituto Nacional de Estadística e Informática- (2008) Perú: Crecimiento y distribución de la población, 2007. Fondo de Población de las Naciones Unidas. Lima-Perú

26. INEI -Instituto Nacional de Estadística e Informática- (2010) Perú: Análisis Etnosociodemográfico de las Comunidades Nativas de la Amazonía, 1993 y 2007. Dirección Técnica de Demografía e Indicadores Sociales - Fondo de población de las Naciones Unidas. Lima, Perú

27. INEI -Instituto Nacional de Estadística e Informática- (2011) Perú: anuario de estadísticas ambientales - 2011. [http://www.inei.gob. pe/BiblioINEIPub/BancoPub/Est/Lib0978/index.html] Accessed 25 January 2014

28. IBGE -Instituto Brasileiro de Geografia e Estatística- (2010) Joint Statistical Publication by BRIC Countries. Brazil, Russia, India, China. Gerência de Editoração/Centro de Documentação e Disseminação de Informações - CDDI/IBGE. Rio de Janeiro, Brazil

29. IUCN (2013) IUCN Red List of Threatened Species. Version 2013.2. Cambridge, United Kingdom [www.iucnredlist.org] Accessed 23 October 2013

30. Iwamura T, Lambin E, Silvius K, Luzar J, Fragoso J (2014) Agentbased modeling of hunting and subsistence agriculture on indigenous lands: Understanding interactions between social and ecological systems. Environmental Modelling \& Software 58:109-127.

31. Johnson FA, Kendall WL, Dubovsky JA (2002) Conditions and limitations on learning in the adaptative management of mallard harvest. Wildlife Society Bulletin 30(1):176-185.

32. Juste J, Fa JE, Perez del Val J, Castroviejo J (1995) Market dynamics of bushmeat species in Equatorial Guinea. Journal of Applied Ecology 32:454-467.

33. Lopes MA, Ferrari SF (2000) Effects of human colonization on the abundance and diversity of mammals in eastern Brazilian Amazonia. Conservation Biology 14(6):1658-1665.

34. Maldonado AM (2010) The Impact of Subsistence Hunting by Tikunas on Game Species in Amacayacu National Park, Colombian Amazon. PhD Thesis, Oxford Brookes University, Oxford, United Kingdom

35. Nasi R, Taber A, van Vliet N (2011) Empty forests, empty stomachs? Bushmeat and livelihoods in the Congo and Amazon Basins. International Forestry Review 13(3):355-368.

36. Novaro AJ, Redford $n$ el textotado esta tabla SD\$5, RichardHansen, C. sturce-Sink Systems in the Neotropics. Conservation
Biology 14(3):713-721on KH, Bodmer RE (2000) Effect of Hunting in Source-Sink Systems in the Neotropics. Conservation Biology 14(3):713-721

37. Ojasti J (2000) Manejo de fauna neotropical. Instituto de Zoología Tropical. Caracas, Venezuela

38. Payan CE (2009) Hunting Sustainability, species richness and carnivore conservation in Colombian Amazonia. PhD Thesis, Department of Biology and Department of Anthropology. University College London and Institute of Zoology, London

39. Peres CA (2001) Synergistic effects of subsistence hunting and habitat fragmentation on Amazonian forest vertebrates. Conservation Biology 15(6):1490-1505.

40. Perez EM (1992) Agouti paca. Mammalian Species 404:1-7.

41. Prance GT (1979) Notes on the vegetation of Amazonia III. The terminology of Amazonian forest types subject to inundation. Brittonia 31:26-38.

42. Riaño E (2003) Organizando su espacio, construyendo su territorio. Transformaciones de los asentamientos Ticuna en la ribera del Amazonas colombiano. Unibiblos, Bogotá, Colombia

43. Rudas A, Prieto A (2005) Flora of the Amacayacu Amazonas National Natural Park, Colombia. Missouri Botanical Garden Press

44. Rushton J, Viscarra R, Viscarra C, Basset F, Baptista R, Brown D (2005) How important is bushmeat consumption in South America: now and in the future?. Odi Wildlife Policy Briefing (1) ODI, London, United Kingdom [http://www.odi.org.uk/resources/ download/2418.pdf] Accessed 23 January 2014

45. Salas LA, Kim JB (2002) Spatial factors and stochasticity in the evaluation of sustainable hunting of tapirs. Conservation Biology 16:86-96.

46. Sampaio PAM (2003) Comércio ilegal de carne de animais silvestres em quatro feiras livres do estuario amazônico, Estado do Pará-Brasil. Undergraduate thesis, Universidade Federal do Pará, Centro de Ciências Biológicas. Belém, Pará, Brazil

47. Shepard JrGH, Levi T, Neves EG, Peres CA, Yu DW (2012) Hunting in ancient and modern Amazonia: Rethinking sustainability. American Anthropologist 114(4):652-667.

48. Sills E, Shanley P, Paumgarten F, de Beer J, Pierce A (2011) Evolving perspectives on non-timber forest products. In: Shackelton S, Shackelton C, Shanley P (eds) Non-timber forest products in the global context. Springer-Verlag Berlin Heidelberg, Germany, pp. 23-51.

49. Smythe N (1987) The paca Cuniculus paca as a domestic source of protein for the neotropical, humid lowlands. Applied Animal Behaviour Science 17(1-2):155-170.

50. Suárez-Mutis M, Mora C, Pérez L, Peiter P (2010) Interacciones transfronterizas y salud en la frontera Brasil-Colombia-Perú. Revista Mundo Amazónico 1:243-266.

51. Tobler MW, Hilbert F, Debeir L, Richard-Hansen C (2013) Estimates of density and sustainable harvest of the lowland tapir Tapirus terrestris in the Amazon of French Guiana using a Bayesian spatially explicit capture-recapture model. Oryx 48(3):410-419.

52. van Vliet N, Quiceno-Mesa MP, Cruz-Antia D, Yagüe B (2014) Carne de monte y seguridad alimentaria en la zona trifronteriza amazónica (Colombia, Perú y Brasil). CGIAR, USAID, CIFOR, Fundación SI, UFAM, Fundación Omacha, Bogotá, D.C.

53. van Vliet N, Nebesse C, Gambalemoke S, Akaibe D, Nasi $R$ (2012) The bushmeat market in Kisangani, Democratic Republic of Congo: implications for conservation and food security. Oryx 46(2):196-203. 
54. WCS (2007) El tráfico de carne silvestre en el Parque Nacional Yasuní: Caracterización de un mercado creciente en la Amazonía norte del Ecuador. Programa Ecuador Boletín No. 2. WCS, Quito, Ecuador [http://s3.amazonaws. com/WCSResources/file_20110823_035823_ecu_pub_ ProgramaEcuadorBoletin2_2007_oAuB.pdf] Accessed 15 July 2014

55. Weinbaum KZ, Brashares JS, Golden CD, Getz WM (2013) Searching for sustainability: are assessments of wildlife harvests behind the times?. Ecology Letters 16(1):99-111.

56. Wilkie DS, Starkey M, Abernethy K, Nstame Effa E, Telfer $P$, Godoy $R$ (2005) Role of prices and wealth in comsumer demand for bushmeat in Gabon, Central Africa. Conservation Biology 19(1):268-274

57. Zapata-Rios G, Urgiles C, Suarez E (2009) Mammal hunting by the Shuar of the Ecuadorian Amazon: is it sustainable?. Oryx 43(3):357-385.

58. Zapata-Ríos G (2001) Sustentabilidad de la cacería de subsistencia: el caso de cuatro comunidades quichuas en la Amazonía nororiental ecuatoriana. Journal of Mammalogy 8(1):59-66.

59. Zarate C (2008) Fronteras en la globalización: localidad, biodiversidad y comercio en la Amazonia. Observatorio Andino. Universidad Javeriana. Fundación Konrad Adenauer. V. 1. ISBN: 978-958-98301-1-6. 